\title{
INFLUENCE OF GLYCOLYSIS PROCESS ON THE FORMATION OF MEAT QUALITY PARAMETERS
}

\section{WPŁYW PROCESU GLIKOLIZY NA KSZTAŁTOWANIE PARAMETRÓW JAKOŚCI MIĘSA}

Department of Genetics and Animal Breeding, West Pomeranian University of Technology, Szczecin, Poland

\begin{abstract}
Streszczenie. Postępujący rozwój technologii produkcji mięsa wieprzowego musi uwzględniać zmieniające się upodobania konsumentów, którzy obecnie przykładają ogromną wagę do jakości surowca. Jakość mięsa nie jest prosta do zdefiniowania, charakteryzuje ją wiele parametrów fizykochemicznych i sensorycznych. Cechą mająca pozytywny wpływ na te parametry jest zawartość tłuszczu śródmięśniowego (IMF). Zawartość IMF wpływa na metabolizm glukozy, a tym samym jest nierozerwalnie związana ze szlakiem glikolitycznym. Pierwszy etap glikolizy katalizowany jest przez enzym heksokinazę, która uczestniczy w nieodwracalnej reakcji fosforylacji glukozy. Jedną z izoform heksokinazy, występującą m.in. w mięśniach szkieletowych oraz tkance mięśniowej, jest heksokinaza 2 (HK2). Ze względu na rolę HK2, jako wiodącego enzymu glikolitycznego w tkankach wrażliwych na insulinę, polimorfizmy genu kodującego to białko mogą mieć wpływ na jego funkcjonowanie. W związku z tym gen HK2 został wybrany jako gen kandydat dla cech jakości wieprzowiny.
\end{abstract}

Key words: glycolysis, intramuscular fat (IMF), hexokinase 2, meat quality, polymorphism.

Słowa kluczowe: glikoliza, tłuszcz śródmięśniowy (IMF), heksokinaza 2, jakość mięsa, polimorfizm.

\section{INTRODUCTION}

Meat quality is not only an especially critical issue for the meat industry of the 21 st century, but also for people, who consume meat - both things are strongly and undeniably connected. Meat producers should consistently provide meat products, which are good-tasting, healthy and most importantly safe for the consumer, as customers' demand for high-quality meat constantly increases in most of developed countries. This would ensure continued consumption of meat products. Therefore, in order to produce meat of high quality is crucial to understand the characteristics of meat quality traits and factors which control these traits (Joo et al. 2013).

Pork is the most commonly consumed type of meat in Poland. According to the Central Statistical Office, in 2015, the average Pole consumed 41.4 kilograms of pork, which is the result of about $5.9 \%$ higher than in 2014 (GUS 2016). Due to the fact that pork is the most preferred type of meat, to ensure its highest quality is one of the biggest challenges for farmers and pig producers.

Corresponding author - Adres do korespondencji: Katarzyna Woźniak, Department of Genetics and Animal Breeding, West Pomeranian University of Technology, Szczecin, Piastów 45, 30-311 Szczecin, Poland, e-mail: katarzyna.wozniak@zut.edu.pl 
In recent years in Poland, a special attention has begun to pay to the intensive breeding of pigs to increase its meatiness. The composition of carcass and quality of pork can be modified by selection, proper nutrition, crossbreeding of breeds and lines. The quality of meat is not easy to define. It can be characterized by a number of physicochemical and sensory parameters (Karpiesiuk et al. 2013).

There is no single definition of high quality meat used in the pork industry today. Meat quality is a combination of subjective and objective measurements that vary across markets, particularly international ones. Some of the most common measurements used in determining the pork quality are color, $\mathrm{pH}$, water retention capacity, firmness, and marbling. As the industry has been learning more about meat quality and how to measure it over the last decade, meat quality has become increasingly important to all segments of pork production (PIC 2016).

For the consumer, however, among a spectrum of parameters characterizing the meat, the most important are: color, tenderness, juiciness, taste and flavor. These sensory parameters are affected by several factors, both life (race, genotype, age of the animal at slaughter, sex, nutrition, breeding conditions, and pre-slaughter performance) and post-slaughter ones (cooling and post-slaughter transformations) - Wajdzik (2015). Creating the optimal level for these factors affecting the quality of pork does not provide a stable and balanced level for the sensory characteristics. Therefore the above-mentioned factors do not determine the full variation in these traits that are so important from the point of view of the consumer. Increase the public awareness with regard to food quality and nutritional aspects of pork contributed to the growth of the rank of studies concerning its quality. Several of them have shown that the characteristics of having a positive effect on pork quality parameters is the content of intramuscular fat (IMF) - Sienkiewicz and Lewandowska (2012).

\section{INTRAMUSCULAR FAT (IMF)}

Intramuscular fat (IMF) is the fat located within the muscle fibers and connective tissue between muscle fiber bundles (Blicharski et al. 2006). It can be obtained from the fat cells and muscle cells and in lesser extent from the free fat in the form of free fatty acids contained in the blood vessels, plasma, and cytoplasm of muscle cells. The IMF is composed of triglycerides $(70 \%)$, phospholipids (25\%), cholesterol esters, cholesterol, and free fatty acids (5\%). Phospholipids and triglycerides are the main components of intramuscular fat. Phospholipids are the major component of cell membranes and their contribution to the contents of IMF is almost constant and comparable in a group of similar muscles, but different between muscles from different types (Shi-Zheng and Su-Mei 2009). The IMF is positively correlated with percentage of red muscle fiber (type I), but negatively with white muscle fiber (type II) in muscle (Hwang et al. 2010). However, as demonstrated in studies performed using pigs, increase in the IMF is mainly caused by an increase in triglycerides. Triglycerides are simple fats, which are a fundamental component of fat tissue and that are used by an organism as an energy source. Body stores them also in the form of adipose tissue, thereby forming a reserve of energy in case of starvation or increased physical activity. Numerous studies have confirmed that the muscle fibers of type I (oxidative) contain much more triglycerides than type II muscle fibers (glycolytic) - Malenfant et al. (2001). 
Levels of IMF in meat may vary and may be affected by a spectrum of factors: species, breed, age, and muscle type (Reardon et al. 2010). Content of IMF is particularly important for consumers, because it contributes to the sensory and culinary quality of pork (among others: color, tenderness, juiciness, taste and scent), as well as fatty acids (FA) composition, which determines its pro-health features (Nguyen et al. 2004; Shi-Zheng and Su-Mei 2009).

Unfortunately, pork obtained from a high-output breeds and lines is characterized by a low level of IMF. The low level of IMF does not refer to all muscles within the carcass, mainly white muscles of a glycolytic character are exposed, including the most valuable in the pork carcass the longest muscle in the back (loin). Breeding programs for pigs are aimed at reducing the level of fat in carcass. However, this should only take place in the direction of reducing the subcutaneous fat. The intramuscular fat content should be systematically raised, because it determines the quality parameters of meat (Tyra and Mitka 2015). It is assumed that meat of good quality have IMF content in the range of $2-3.5 \%$ (Wood 2008). The IMF level lower than $1 \%$ is considered unacceptable, threatening the poorer flavor, juiciness and fragility of meat, which after thermal processing becomes dry and tough (Schwörer et al. 2000).

Development of traits such as fatness, IMF and fatty acid composition is closely related to lipid and energy metabolism. Intramuscular fat content (IMF) affects the glucose uptake and the metabolism and health of humans and animals. Elevated levels of intramyocellular lipids can be a sign of impaired utilization of fatty acids as energy fuel or even insulin resistance. In addition, high intramuscular triglyceride levels, which are highly correlated with high body fat mass, inhibit the insulin-signaling cascade and lower the glucose uptake. Genome scans have identified a large number of QTL affecting these traits in pigs. Accordingly, genes, which encode key enzymes or key regulators in lipid and energy metabolism located within relevant QTL regions, are logical choices in the candidate gene analysis for these traits (Chadt et al. 2008; Lin 2009; Kärst et al. 2011).

\section{GLYCOLYSIS}

Discovery of glycogen by Bernard in 1857 can be conventionally taken as the beginning of studies upon carbohydrates metabolism. However, discovery of glucose metabolism, or glycolysis, occurred in the thirties of the last century. Glycolysis, also referred to as the Embden-Meyerhof-Parnas pathway, is a series of biochemical reactions, during which one molecule of glucose is converted into two molecules of pyruvate.

The overall reaction of glycolysis is (Murray et al. 2006):

glucose $+2 \mathrm{Pi}+2 \mathrm{ADP}+2 \mathrm{NAD}+\rightarrow 2$ molecules of pyruvate $+2 \mathrm{ATP}+2 \mathrm{NADH}+2 \mathrm{H}^{+}+2 \mathrm{H}_{2} \mathrm{O}$ where:

$\mathrm{Pi}-\mathrm{HPO}_{4}{ }^{2-}$, inorganic phosphate,

ADP - adenosine diphosphate,

$\mathrm{NAD}^{+}$- oxidized nicotinamide adenine dinucleotide,

ATP - adenosine triphosphate,

$\mathrm{NADH}$ - reduced nicotinamide adenine dinucleotide,

$\mathrm{H}^{+}-$hydrogen ion (proton),

$\mathrm{H}_{2} \mathrm{O}$ - chemical formula for water. 
This process is widely distributed among living organisms belonging to all three domains. Studies have shown that in eukaryotes, this metabolic pathway is present in almost all cells and occurs in the primary cytoplasm.

In cells of individual tissues, such as muscles and liver, various glycolysis isoenzymes were found, which catalyze the same reactions. Studies have also shown that glycolysis is strictly regulated. Although most of the glycolytic reactions are reversible, three of them are clearly exoergic and therefore have to be considered as physiologically irreversible reactions. These are reactions catalyzed by hexokinase, phosphofructokinase, and pyruvate kinase. These reactions are essential sites of glycolysis regulation (Dżugaj 2004; Murray et al. 2006). When pigs experience stress, glycogen is converted to lactate through glycolysis. This lactate accumulates in the muscle, resulting in a muscle $\mathrm{pH}$ decline which causes the denaturation of muscle proteins. This is strongly connected with meat characteristic parameters, especially tenderness, water-holding capacity and color (Schäfer et al. 2002; Choe et al. 2015).

\section{HEXOKINASES}

Hexokinases - HKs (EC 2.7.1.1) catalyze the first step of glucose metabolism (Glc), phosphorylating glucose to glucose 6-phosphate (G6P). The subsequent steps vary, as the glucose 6-phosphate formed in the first step may have different metabolic fates in different types of cell and in different physiological conditions (Fig. 1).

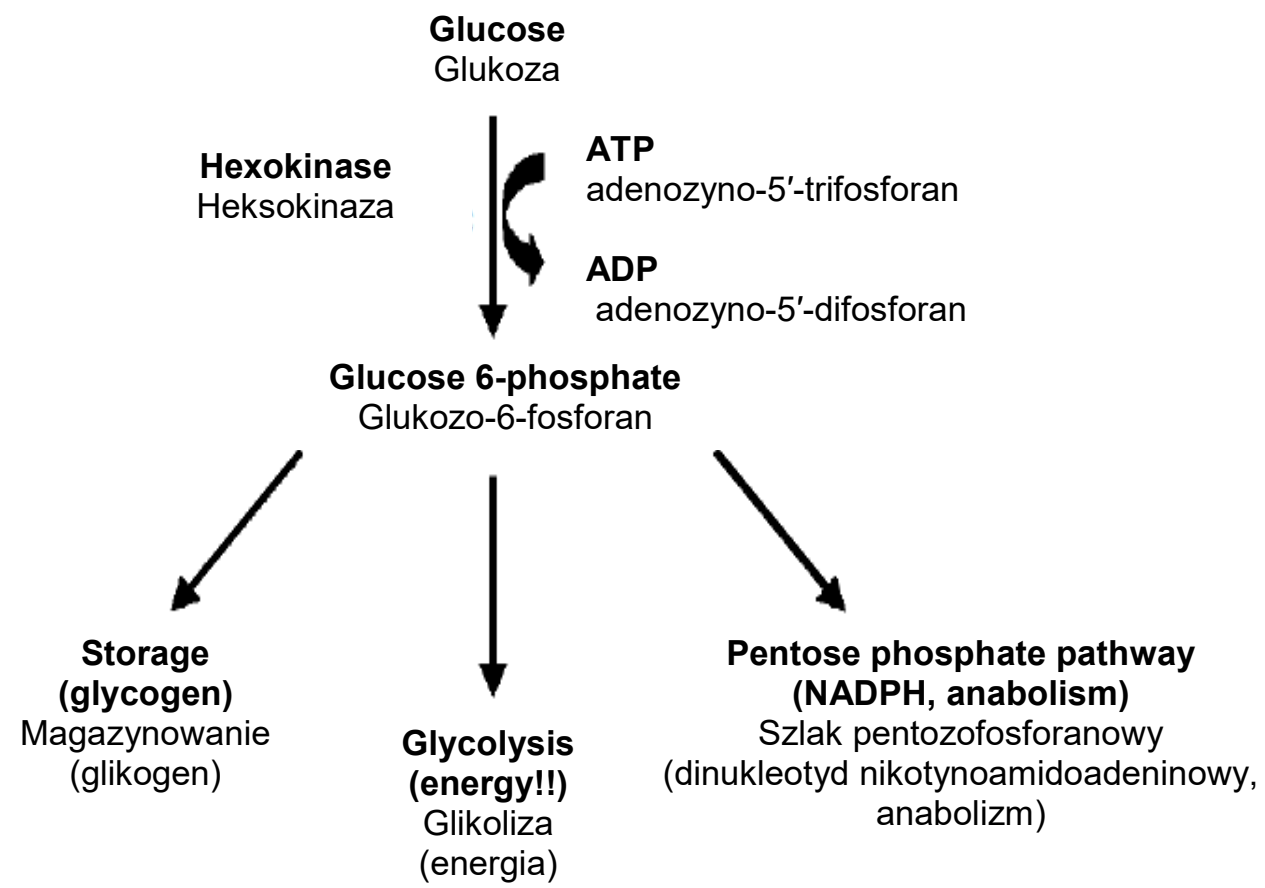

Fig. 1. Phosphorylation catalyzed by hexokinase is the initial step in common pathways of Glc metabolism Ryc. 1. Fosforylacja katalizowana przez heksokinazę - pierwszy etap matabolizmu glukozy Source - Źrodło: Wilson (2003). 
Vertebrate tissues contain up to four isoenzymes designated as hexokinases 1, 2, 3 and 4 on the basis of their electrophoretic mobility; hexokinase 4 is often called 'glucokinase', but this name is unfortunate, because four isoenzymes do not differ in their specificity for glucose (Wilson 2003; Tan and Miyamoto 2015).

\section{HEXOKINASE 2}

Hexokinase 2 (HK2) plays an important role in intracellular glucose metabolism by catalyzing the conversion of glucose to glucose-6-phosphate. Hexokinase 2 has been demonstrated to play the role of a key enzyme member in the glycolysis reaction. HK2 encodes hexokinase 2, which is the predominant isoform in insulin-sensitive tissues such as heart, skeletal muscle, and adipose tissues. It is localized in the outer membrane of mitochondria. Expression of this gene is insulin-responsive; namely, insulin has been shown to increase transcription of this gene (Jun et al. 2006; Jun et al. 2012; Tan and Miyamoto 2015). By catalyzing the phosphorylation of glucose to yield glucose-6-phosphate, hexokinases maintain the downhill concentration gradient that favors the facilitated transport of glucose into cells. This reaction also initiates all physiologically relevant pathways of glucose utilization, including glycolysis and the pentose phosphate pathway. This gene encoding the hexokinase 2 (HK2) has been mapped on the porcine chromosome 3 and contains 18 encoding regions ( $\mathrm{NCBI}$, Gene ID: 494561) - Fig. 2.

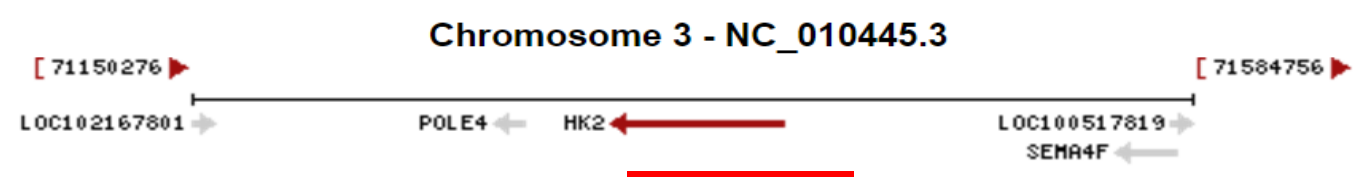

Fig. 2. HK2 gene location on chromosome 3 in pigs

Ryc. 2. Lokalizacja genu HK2 na chromosomie 3 świń

Source - Żródło: HK2 hexokinase 2 [Sus scrofa (pig)], https://www.ncbi.nlm.nih.gov/gene/494561.

This gene encodes the 917-residue enzyme of $100-\mathrm{kDa}$, whose $\mathrm{N}$ - and $\mathrm{C}$ - terminal domains are of a high similarity and each of them form half of the protein. Both $\mathrm{N}$ - and C-terminal domains are characterized by catalytic ability, which can be inhibited by G6P. Nevertheless, the C-terminal domain is of a lower affinity for ATP, therefore it can be inhibited at only high concentrations of G6P. Despite the fact, that there are two binding sites for glucose, it has been proposed, that the glucose binding at one side triggers a conformational change, which prevents the second glucose from binding to the other site (Printz et al. 1997; Ahn et al. 2009).

\section{CONCLUSION}

The changing lifestyles affect the consumption habits of all social groups. Conscious consumer knows exactly what should be expected from purchased product. Increasing consumer's awareness translates into manufacturers, who are forced to sell fatteners with 
a specific tissue composition. Therefore, the activities are carried out to make a good quality raw material and healthy, tasty products obtained in the processing, target the consumer's expectations and implement the growing demand for pork. Intramuscular fat is necessary for extracting the meat values that affect its quality. Genetic improvement of meat quality traits such as IMF, is difficult to achieve through traditional selection methods due to the need for extensive and expensive measurements of such traits on slaughtered relatives. Nevertheless, it is expected that knowledge of the underlying genes for these traits will greatly contribute to the effective selection (Lin 2009). Due to the role of HK2 as a leading glycolytic enzyme in insulin-sensitive tissues such as skeletal muscle, heart, and adipose tissue, defects in HK2 function could contribute to the important direct roles for traits related to skeletal muscle and fat. Therefore, HK2 gene was selected as a candidate gene for the pig production traits. This gene was chosen to investigate the contribution of genetics to pork quality (Jun et al. 2012).

\section{REFERENCES}

Ahn K.J., Kim J., Yun M., Park J.H., Lee J.D. 2009. Enzymatic properties of the N- and C-terminal halves of human hexokinase II. BMB Rep. 42(6), 350-355.

Blicharski T., Hammermeister A., Pierzchała M. 2006. Zawartość tłuszczu śródmięśniowego w mięsie wieprzowym. Gosp. Mięs. 6(58), 30-33. [in Polish]

Chadt A., Leicht K., Deshmukh A., Jiang L.Q., Scherneck S., Bernhardt U., Dreja T., Vogel H., Schmolz K., Kluge R., Zierath J.R., Hultschig C., Hoeben R.C., Schurmann A., Joost H.G., Al-Hasani H. 2008. Tbc1d1 mutation in lean mouse strain confers leanness and protects from diet-induced obesity. Nat. Genet. 40, 1354-1359.

Choe J.H., Choi M.H., Ryu Y.C., Go G.W., Choi Y.M., Lee S.H., Lim K.S., Lee E.A., Kang J.H., Hong K.C., Kim B.C. 2015. Estimation of pork quality traits using exsanguination blood and postmortem muscle metabolites. Asian-Australas J. Anim. Sci. 28(6), 862-869.

Dżugaj A. 2004. Węglowodany i ich metabolizm. Uniwersytet Wrocławski, Instytut Genetyki i Mikrobiologii, www.fundacjarozwojunauki.pl, access: January 2017. [in Polish]

Główny Urząd Statystyczny. 2016. Rocz. Statyst. Rol. 2015. [in Polish]

HK2 hexokinase 2 [Sus scrofa (pig)], https://www.ncbi.nlm.nih.gov/gene/494561, access: January 2017.

Hwang Y.H., Kim G.D., Jeong J.Y., Hur S.J., Joo S.T. 2010. The relationship between muscle fiber characteristics and meat quality traits of highly marbled Hanwoo (Korean native cattle) steers. Meat Sci. 86, 456-461.

Joo S.T., Kim G.D., Hwang Y.H., Ryu Y.C. 2013. Control of fresh meat quality through manipulation of muscle fiber characteristics. Meat Sci. 95, 828-836.

Jun W., Chang-Yan D., Yuan-Zhu X., Bo Z. 2012. Association analysis of polymorphism in intron-10 of Porcine HK2 gene with meat quality and carcass traits. J. Anim. Vet. 11, 1158-1161.

Jun W., Chang-Yan D., Yuan-Zhu X., Bo Z., Huan-Chen C., Fenge L., Ming-Gang L., Rong Z., Si-Wen J. 2006. Sequencing, polymorphism and expression profile analysis of porcine Hexokinase II (HK2) Gene. Agr. Sci. China. 5, 384-389.

Karpiesiuk K., Kozera W., Bugnacka D., Falkowski J. 2013. Wpływ warunków chowu tuczników na jakość mięsa i profil kwasów tłuszczowych w mięśniu najdłuższym grzbietu [Effect of rearing system conditions of fatteners on meat quality and profile of fatty acids in $\mathrm{m}$. Longissimus dorsi]. Żywn. Nauk. Technol. Jakość 20, 3(88), 39-50. [in Polish]

Kärst S., Cheng R., Schmitt A.O., Yang H., Villena F.P.M., Palmer A.A., Brockmann G.A. 2011. Genetic determinants for intramuscular fat content and waterholding capacity in mice selected for high muscle mass. Mamm. Genome 22(9-10), 530-543. 
Lin L. 2009. Genomic characterization and polymorphism analysis of genes involved in lipid- and energy metabolism in swine. PhD thesis. Technische Universität München, 2-22. [typescript]

Malenfant P., Joanisse D.R., Thériault R., Goodpaster B.H., Kelley D.E., Simoneau J.A. 2001. Fat content in individual muscle fibers of lean and obese subjects. Int. J. Obes. Relat. Metab. Disord. 25(9), 1316-1321.

Murray R.K., Granner D.K., Rodwell V.W. 2006. Biochemia Harpera. Warszawa, Wydaw. Lek. PZWL, 185-204. [in Polish]

Nguyen N.H., Macphee C.P., Wade C.M. 2004. Genetic selection for efficient lean growth in pigs. Pigs News Inf. 25, 149-163.

PIC, USA. 2016. Technical update. Pork meat quality: Understanding industry measurements and guidelines, www.pic.com/usa, access: January 2017.

Printz R.L., Osawa H., Ardehali H., Koch S., Granner D.K. 1997. Hexokinase II gene: structure, regulation and promoter organization. Biochem. Soc. Trans. 25(1), 107-112.

Schäfer A., Rosenvold K., Purslow P.P., Andersen H.J., Henckel P. 2002. Physiological and structural events post mortem of importance for drip loss in pork. Meat. Sci. 61, 355-366.

Schwörer D., Hofer A., Lorenz D., Rebsamen A. 2000. Selection progress of intramuscular fat in Swiss pig production, in: Conference paper on quality of meat and fat in pigs as affected by genetics and nutrition. Zurich, August 25, 1999. Zurich, Switzerland, EAAP, 69-72.

Shi-Zheng G., Su-Mei Z. 2009. Physiology, affecting factors and strategies for control of pig meat intramuscular fat. Rec. Pat. Food Nutr. Agric. 1, 59-74.

Sienkiewicz J., Lewandowska D. 2012. Czynniki wpływające na jakość mięsa wieprzowego [Factors effecting quality of pork meat]. Zesz. Nauk. Ostroł. Tow. Nauk. 26, 261-272. [in Polish]

Tan V.P., Miyamoto S. 2015. HK2/hexokinase-II integrates glycolysis and autophagy to confer cellular protection. Autophagy 11(6), 963-964.

Tyra M., Mitka I. 2015. Rola tłuszczu śródmięśniowego (IMF) w kształtowaniu parametrów jakościowych (sensorycznych) mięsa [The role of imf in forming meat quality (sensory) parameters]. Wiad. Zoot. 53(4), 50-56. [in Polish]

Wajdzik J. 2016. Czynniki poubojowe kształtujące jakość wieprzowiny. Ogól. Inf. Mas. 248, 22-32. [in Polish]

Wilson J.E. 2003. Isozymes of mammalian hexokinase: structure, subcellular localization and metabolic function. The J. Exp. Biol. 206, 2049-2057.

Wood J.D., Enser M., Fisher A.V., Nute G.R., Sheard P.R., Richardson R.I, Hughes S.I., Whittington F.M. 2008. Fat deposition, fatty acid composition and meat quality: A review. Meat. Sci. 78(4), 343-358.

Abstract. Development of technologies for pork production has to take into account the changing tastes of consumers, who are now attach great importance to the quality of raw material. The quality of meat is not easy to define, because it is characterized by a number of physicochemical and sensory parameters. A feature having a positive effect on these parameters is the content of intramuscular fat (IMF). The content of IMF influences on glucose metabolism, and thus is inextricably linked to the glycolytic pathway. The first step of glycolysis is catalyzed by the enzyme hexokinase that participates in the irreversible glucose phosphorylation reaction. One of the hexokinase isoforms occurring in skeletal muscles and muscle tissue is hexokinase 2 (HK2). Due to the role of HK2 as a leading glycolytic enzyme in insulin-sensitive tissues, polymorphisms of the gene encoding this protein can affect its function. Therefore, the gene HK2 has been selected as a candidate gene for pork quality characteristics. 
